Prepared in cooperation with the U.S. Fish and Wildlife Service

\title{
Fish Tag Recovery from Anaho Island Nesting Colony, Pyramid Lake, Nevada
}

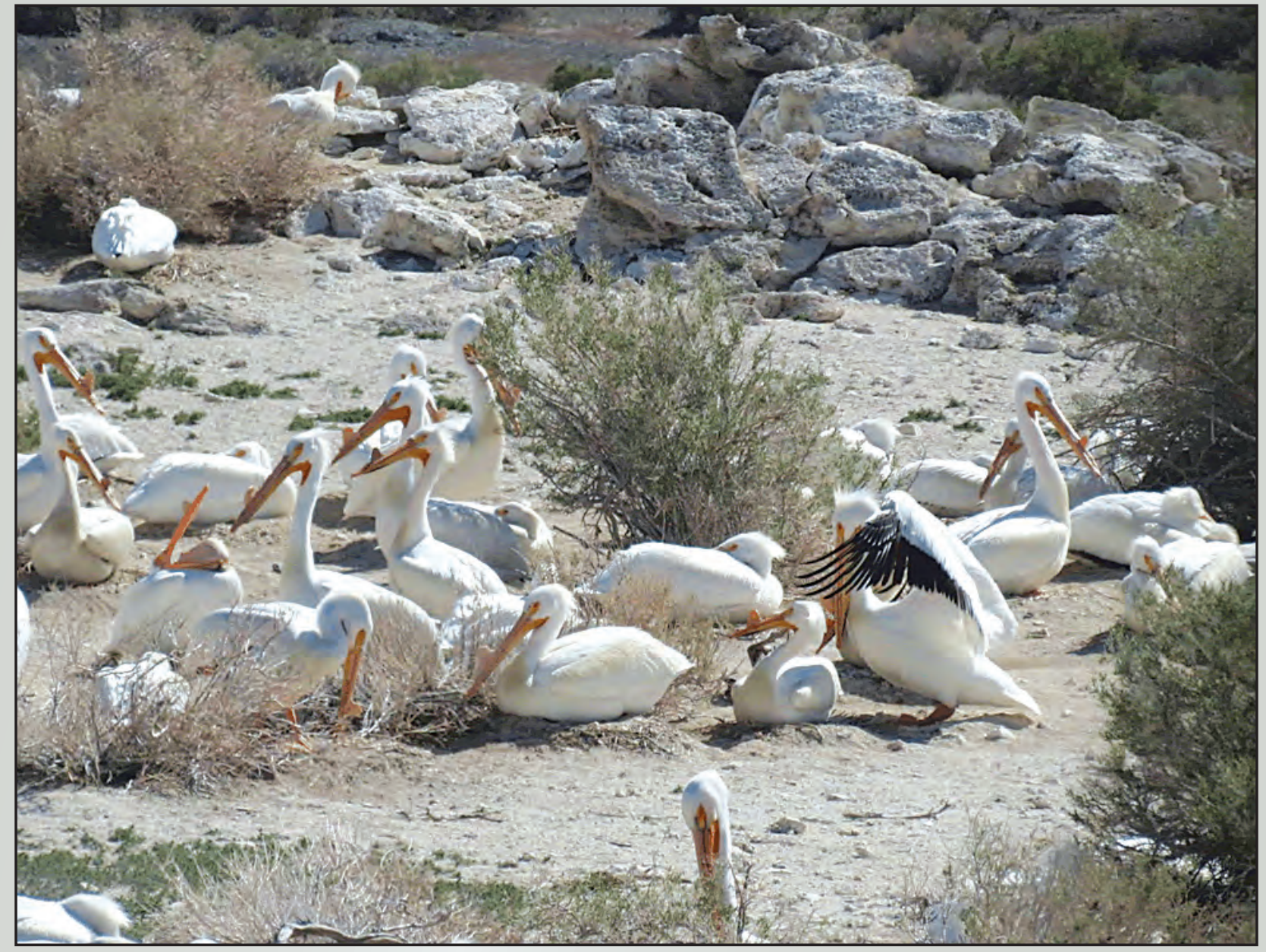

Open-File Report 2015-1242

U.S. Department of the Interior

U.S. Geological Survey 
Cover: Photograph showing American White Pelican on the Anaho Island nesting colony, Pyramid Lake, Nevada. Photograph by Donna Withers, U.S. Fish and Wildlife Service, 2013. 


\section{Fish Tag Recovery from Anaho Island Nesting Colony, Pyramid Lake, Nevada}

By G. Gary Scoppettone, Mark C. Fabes, Peter H. Rissler, and Donna Withers

Prepared in cooperation with the U.S. Fish and Wildlife Service

Open-File Report 2015-1242

U.S. Department of the Interior

U.S. Geological Survey 


\section{U.S. Department of the Interior \\ SALLY JEWELL, Secretary}

\section{U.S. Geological Survey \\ Suzette M. Kimball, Director}

U.S. Geological Survey, Reston, Virginia: 2016

For more information on the USGS-the Federal source for science about the Earth, its natural and living resources, natural hazards, and the environment-visit http://www.usgs.gov/ or call 1-888-ASK-USGS (1-888-275-8747).

For an overview of USGS information products, including maps, imagery, and publications, visit http://www.usgs.gov/pubprod/.

Any use of trade, firm, or product names is for descriptive purposes only and does not imply endorsement by the U.S. Government.

Although this information product, for the most part, is in the public domain, it also may contain copyrighted materials as noted in the text. Permission to reproduce copyrighted items must be secured from the copyright owner.

\section{Suggested citation:}

Scoppettone, G.G., Fabes, M.C., Rissler, P.H., and Withers, Donna, 2016, Fish tag recovery from Anaho Island nesting colony, Pyramid Lake, Nevada: U.S. Geological Survey Open-File Report 2015-1242, 28 p., http://dx.doi.org/10.3133/ofr20151242.

ISSN 2331-1258 (online) 


\section{Contents}

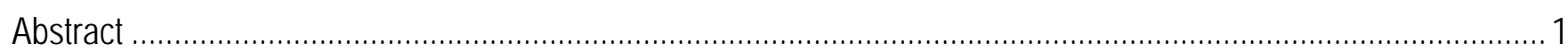

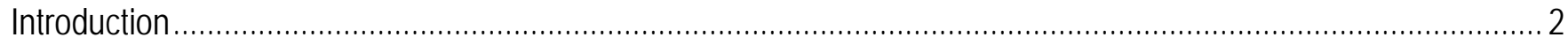

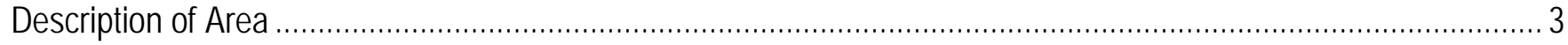

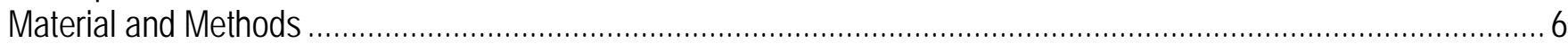

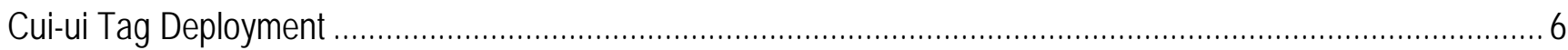

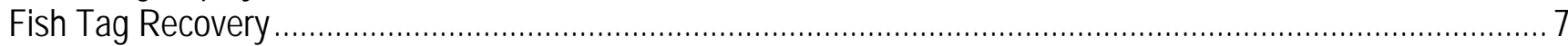

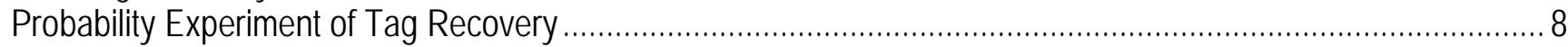

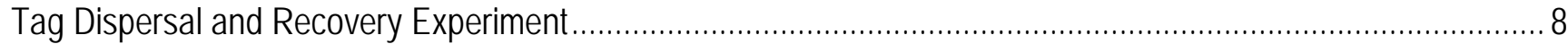

Tagged Fish Fed to Pelican and Tags Dispersed …………............................................................... 10

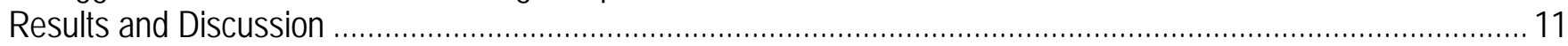

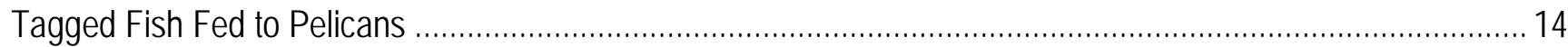

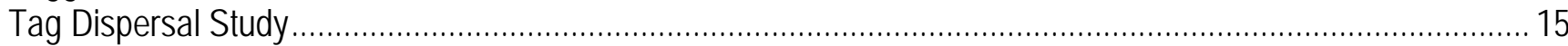

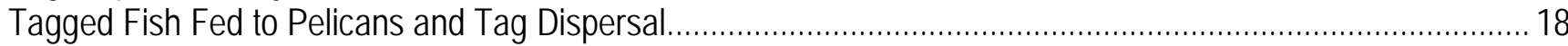

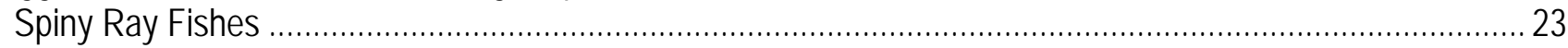

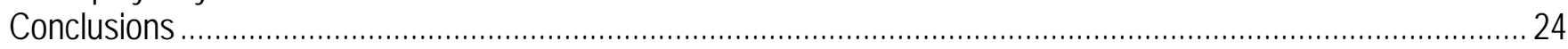

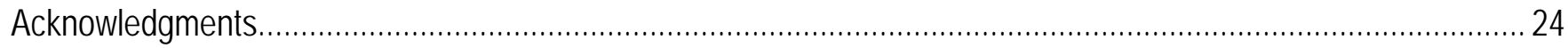

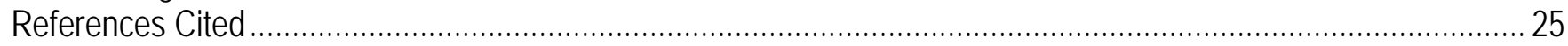

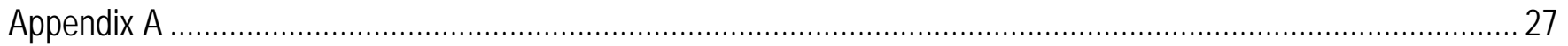

\section{Figures}

Figure 1. Location of Anaho Island at Pyramid Lake, Nevada, with connecting waters. ...................................... 4

Figure 2. Boundaries of Anaho Island nesting sub-colony areas, Pyramid Lake, Nevada, 2014 .......................... 5

Figure 3. Locations of dispersal tags and tag deployment areas on Anaho Island nesting colony, Pyramid Lake, Nevada.

Figure 4. Density distribution of cui-ui (Chasmistes cujus) tags recovered from Anaho Island nesting sub-colonies, Pyramid Lake, Nevada, 2001-14...

Figure 5. Areal distribution of recovered tags dispersed on the Anaho Island nesting colony, Pyramid Lake, Nevada.

Figure 6. Assortment of hooked lures and stringers gathered from the Anaho Island nesting colony, Pyramid Lake, Nevada, 2001-2014.

Figure 7. Locations of tagged fish deployment taken by American White Pelican (Pelecanus erythrorhynchos) back to Anaho Island nesting colony, Pyramid Lake, Nevada 


\section{Tables}

Table 1. History of cui-ui tags recovered from Anaho Island nesting colony, Pyramid Lake, Nevada, 2001-14 _.... 6

Table 2. Total number of tags recovered from 1,179 common carp (Cyprinus carpio) and Lahontan cutthroat trout (Oncorhynchus clarkii henshawi) fed to pelicans, Anaho Island nesting colony, Pyramid Lake, Nevada, springs of 2011 and 2012.

Table 3. Total number of recovered tags dispersed throughout Anaho Island nesting colony, Pyramid Lake, Nevada.

Table 4. Dispersal tags deployed by sub-colony, tags recovered, and frequency of tag recovery,

Anaho Island nesting colony, Pyramid Lake, Nevada.

Table 5. Two sample Z-test to compare sample proportion for significance between tag recovery passes,

Anaho Island nesting colony, Pyramid Lake, Nevada.....

Table 6. History of salmonid tags recovered from Anaho Island nesting colony, Pyramid Lake, Nevada.

Table 7. History of spiny ray fish tags recovered from Anaho Island nesting colony, Pyramid Lake, Nevada

\section{Conversion Factors}

International System of Units to Inch/Pound

\begin{tabular}{lcl}
\hline Multiply & By & To obtain \\
\hline & Area & \\
\hline square kilometer $\left(\mathrm{km}^{2}\right)$ & 0.3861 & square mile \\
\hline & Length & \\
\hline meter $(\mathrm{m})$ & 39.37 & inch \\
millimeter $(\mathrm{mm})$ & 0.0393 & inch \\
kilometer $(\mathrm{km})$ & 0.6213 & mile \\
\hline
\end{tabular}

Temperature in degrees Celsius $\left({ }^{\circ} \mathrm{C}\right)$ may be converted to degrees Fahrenheit $\left({ }^{\circ} \mathrm{F}\right)$ as follows:

$$
{ }^{\circ} \mathrm{F}=\left(1.8 \times{ }^{\circ} \mathrm{C}\right)+32 \text {. }
$$




\title{
Fish Tag Recovery from Anaho Island Nesting Colony, Pyramid Lake, Nevada
}

\author{
By G. Gary Scoppettone ${ }^{1}$, Mark C. Fabes ${ }^{1}$, Peter H. Rissler ${ }^{1}$, and Donna Withers ${ }^{2}$
}

\begin{abstract}
In 2001, tags applied to the federally endangered species cui-ui (Chasmistes cujus) to study their population dynamics were discovered strewn throughout the American White Pelican (Pelecanus erythrorhynchos) nesting colony on Anaho Island, Pyramid Lake, Nevada. Cui-ui are endemic to Pyramid Lake, and Anaho Island harbors one of North America's largest nesting colonies of American White Pelican. Cui-ui are consumed by pelicans during the fish's spring migration into the Truckee River to reproduce. The predatory success of pelican has been validated by determining the odds of finding a tag from a predated cui-ui within the Anaho Island nesting colony. It is unknown how many cui-ui tags are eliminated by birds before arrival to the colony versus how many are brought to the colony but never recovered. The focus of this study was to improve the estimate of the chances of collecting a tag from a predated adult cui-ui in the pelican nesting colony by feeding dead tagged Lahontan cutthroat trout (Oncorhynchus clarkii henshawi) and common carp (Cyprinus carpio) to pelican and subsequently searching for these tags within the colony. We also randomly deployed 1,000 dispersal tags throughout the nesting colony, searching for these after one and two breeding seasons. After adding 1,027 fed fish to 547 previously fed fish, we estimated 5.3 percent of the tagged cui-ui taken by pelican were recovered during tag searches. A study of dispersal tags randomly deployed within the pelican nesting colony showed that 51.5 percent would be expected to be recovered after at least one breeding season after being deployed. Results of our studies indicate that more than 90 percent of tags from adult cui-ui are eliminated by birds outside the pelican nesting colony. Tags recovered from other species and the site at which they were tagged are also reported. Most notable were recovered Lahontan cutthroat trout tags, which were the highest in number, but their proximity to double-crested cormorant (Phalacrocorax auritus) nests suggests this species to be the primary predator. Tags from other species of fish came from as far as the Columbia River, Washington (about 600 kilometers). This study provides an important baseline for future tag recovery from the pelican nesting colony on Anaho Island and opens new questions to American White Pelican movement patterns.
\end{abstract}

\footnotetext{
${ }^{1}$ U.S. Geological Survey.

${ }^{2}$ U.S. Fish and Wildlife Service.
} 


\section{Introduction}

Colonial piscivorous birds have the capacity to consume substantial portions of anthropogenically valued fish populations (Collis and others, 2002; Dalton and others, 2009; Scoppettone and others, 2014). Bioenergetics models have frequently been used to quantify fish consumed by piscivorous birds (Madenjian and Gabrey, 1995; Derby and Lovvorn, 1997; Wiese and others, 2008; Dalton and others, 2009). Another means of assessing the effect of predatory birds on fish populations is the detection and enumeration of fish tags eliminated by birds within a nesting colony (Collis and others, 2001; Scoppettone and others, 2006). However, without the knowledge of the probability of detecting a bird-ingested tag from a given marked fish population, this method lacks accuracy (Collis and others, 2001). These ratios have been established for the predator/prey relationship between American White Pelican (Pelecanus erythrorhynchos) and cui-ui (Chasmistes cujus) at Pyramid Lake, Nevada (Scoppettone and others, 2014), providing a unique opportunity to use fish tags for gauging the influence of American White Pelican on the adult cui-ui population and for evaluating the importance of cui-ui to their diet.

American White Pelican nest on Pyramid Lake’s largest island (Anaho Island), a National Wildlife Refuge within the confines of the Pyramid Lake Paiute Indian Reservation (Anaho Island National Wildlife Refuge). Pelicans begin arriving at Pyramid Lake in late winter coming from southern California and Mexico (Seegar and Fuller, 1997). At about the same time, adult cui-ui, which are obligate lake dwellers but stream spawners, migrate to the mouth of Pyramid Lake’s only perennial tributary, the Truckee River (Scoppettone and others, 1986, 2006). The American White Pelican is not a diving bird, so cui-ui typically become vulnerable to pelican predation when they enter the river on their spawning migration. Cui-ui are not an annual reliable food source for pelicans because they frequently skip spawning due to insufficient streamflow (Scoppettone and others, 1986, 2000). However, cui-ui can incur high mortality attributable to pelican predation when a spawning migration is attempted (Scoppettone and others, 2014).

Although the probability of detecting a tag within the nesting colony from a tagged cui-ui ingested by a pelican has been established, the fate of pelican-ingested tags not detected in the colony is unknown. In this paper, we research the question of how many tags deployed on adult cui-ui arrived to the pelican nesting colony but went undetected versus how many were eliminated by birds outside the colony. This information is important because these data will enable future assessments of tags collected within the nesting colony for future tagging of cui-ui or other fish species. In this paper, we also report on all tags from all fish species collected from Anaho Islands' colonial bird populations including when and where they were tagged and released. Information from this study is intended to give managers some insight into the influence of predatory birds on their subject tagged fish and provide a baseline for further research. 


\section{Description of Area}

Pyramid Lake is approximately $467 \mathrm{~km}^{2}$ in total area and lies within the Pyramid Lake Indian Reservation in west-central Nevada. Anaho Island is approximately $720 \mathrm{~m}$ off the eastern shore of Pyramid Lake and about $12 \mathrm{~km}$ northeast of the mouth of the Truckee River (fig. 1). The American White Pelican nesting colony occupies approximately 11 ha of Anaho Island's 300 ha area and is primarily on the eastern side of the island. The colony is comprised of seven sub-colonies separated by $50 \mathrm{~m}$ or more of no apparent nesting activity (fig. 2). American White Pelican are ground nesters (Evans and Knopf, 1993), and their nesting areas were not only defined by their large round nest, but by trampling activity of adults and juveniles with typically no signs of perennial vegetation nearby. Within the colony, there are patches of greasewood (Sarcobatus vermiculatus) and localized areas of tufa rock. Ground substrate is comprised of loose gravel, sand, broken tufa rock, and gastropod shells. Several species of colonial nesting waterfowl nest on Anaho Island (Scoppettone and others, 2006), but pelican nests were most closely associated with nests of double-crested cormorant (Phalacrocorax auritus). Cormorant nests, which were largely constructed of greasewood, along with their respective ground activity, contributed to defining the colony's boundaries. There was some movement in colony boundaries during the study leading to a slightly greater search area over time.

American White Pelican prey upon cui-ui along the lower $18 \mathrm{~km}$ of the Truckee River, but are most successful at anthropogenically caused impediments to cui-ui migration. Most outstanding was the formation of a shallow delta at the mouth of the Truckee River caused by water diversion from the system (La Rivers, 1962). The shallow delta restricts fish passage in many years and is an area of pelican congregation and fish predation. The Marble Bluff Complex was completed in 1975 to mitigate the negative impacts to the Pyramid Lake fishery caused by federally funded water diversion from the Truckee River. The complex consists of Marble Bluff Dam, constructed approximately $5 \mathrm{~km}$ upstream of the mouth of the Truckee River, and serves to divert water down a $5 \mathrm{~km}$ bypass channel (Marble Bluff Fishway) to the delta, and also stabilizes the river upstream, which became erosive following the water-level decline of Pyramid Lake (Glancy and others, 1972). The dam has a trap and elevator to pass fish upstream should they successfully negotiate the delta. Marble Bluff Fishway has ice harbor type

fish ladders along its course. Although the Marble Bluff Complex has been successful in facilitating fish passage, migratory impediments caused by the dam and ladders are areas of heavy pelican predation during the cui-ui spawning migration. Another site of notable predation is Numana Dam approximately $18 \mathrm{~km}$ upstream of the Truckee River mouth. Numana Dam is also fitted with a fish ladder, but it impedes migration sufficiently to become an area of heavy pelican predation (Scoppettone and others, 2014). 


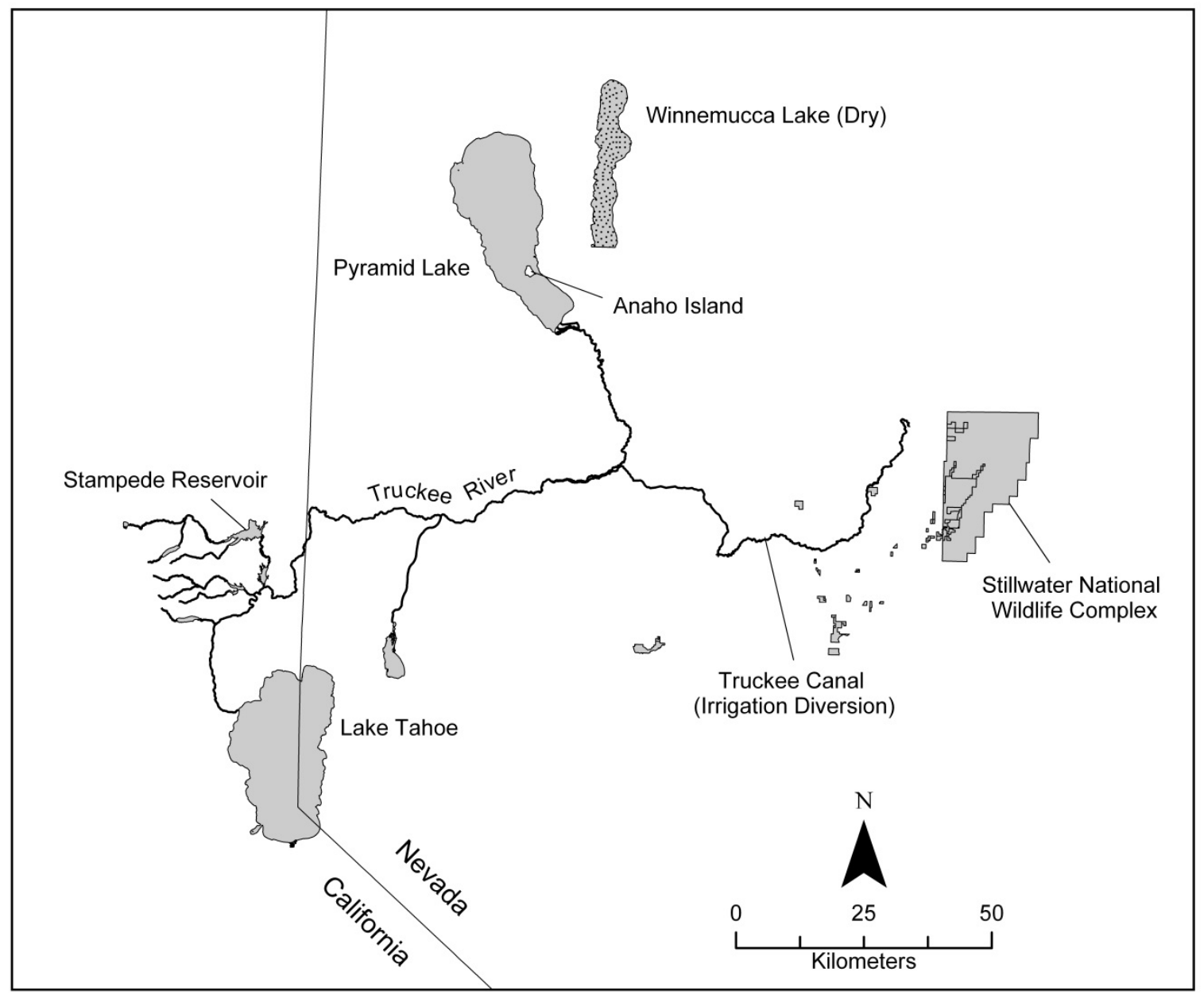

Figure 1. Location of Anaho Island at Pyramid Lake, Nevada, with connecting waters. 


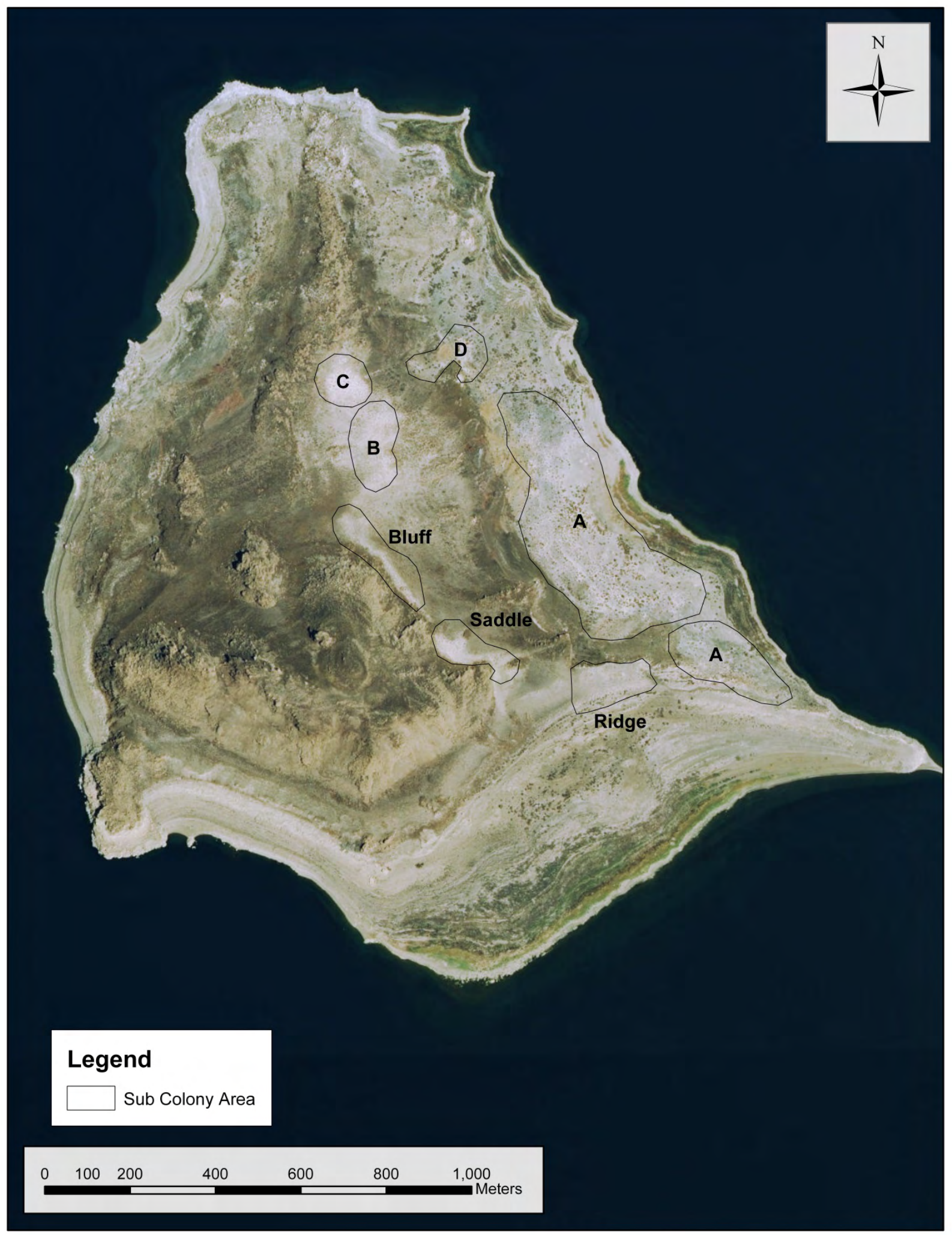

Figure 2. Boundaries of Anaho Island nesting sub-colony areas, Pyramid Lake, Nevada, 2014. 


\section{Material and Methods}

\section{Cui-ui Tag Deployment}

There is a long history of fish tag deployment on cui-ui (Koch, 1972; Sonnevil, 1981;

Scoppettone and others, 1986, 2014). Tags were of several types and deployed by several organizations. A list of tags deployed, deployment dates, and organizations deploying tags is shown in table 1.

There was a substantial increase in cui-ui deployment from 1989 through 2006 associated with a multi-year cui-ui population dynamics study. Within this time period, 10-mm-long numbered T-bar anchor tags were deployed on cui-ui netted annually from their spring-time prespawning aggregation to determine adult survival rate (Scoppettone and others, 2015) and around the periphery of the lake to determine juvenile survival rates. Number and tag color along with demographic information of captured fish were entered into a database at the time of tag deployment.

Table 1. History of cui-ui tags recovered from Anaho Island nesting colony, Pyramid Lake, Nevada, 2001-14.

[MBD, Marble Bluff Dam; PLPT, Pyramid Lake Paiute Tribe; RFS, Reno Field Station (currently under the U.S. Geological Survey, formerly under the U.S. Fish and Wildlife Service Region 8, and the National Biological Survey); UNR, University of Nevada Reno; USFWS, U.S. Fish and Wildlife Service]

\begin{tabular}{lllllrr}
\hline \multicolumn{1}{c}{$\begin{array}{c}\text { Release } \\
\text { organization }\end{array}$} & \multicolumn{1}{c}{ Tag type } & $\begin{array}{c}\text { Deployment } \\
\text { date }\end{array}$ & $\begin{array}{c}\text { Release } \\
\text { location }\end{array}$ & \multicolumn{1}{c}{ Season } & $\begin{array}{c}\text { Number } \\
\text { deployed }\end{array}$ & $\begin{array}{c}\text { Number } \\
\text { recovered }\end{array}$ \\
\hline UNR - Dave Koch & Carlin & $1970-1972$ & River mouth & Spring & 329 & 1 \\
USFWS & Carlin & $1976-1985$ & River mouth & Spring & 2,704 & 24 \\
PLPT Hatchery & Carlin & 1980 & River mouth & Spring & NA & 1 \\
USFWS & T-bar anchor & $1982-1985$ & River mouth & Spring & 3,082 & 7 \\
USFWS & Sonic & 1983 & River mouth & Spring & 6 & 1 \\
USFWS & T-bar anchor & $1984-1987$ & MBD & Spring & 515 & 1 \\
RFS & PIT & 1988 & Lake periphery & Summer & 278 & 0 \\
RFS & PIT & 1989 & River mouth & Spring & 743 & 0 \\
RFS & T-bar anchor & $1989-2006$ & River mouth & Spring & 251,749 & 7,357 \\
RFS & T-bar anchor & $1988-2006$ & Lake periphery & Year round & 84,022 & 1,776 \\
RFS & T-bar anchor & 1997 & MBD & Spring & 5,088 & 354 \\
RFS & T-bar anchor & $1988-2006$ & & (unreadable tags) & & 1,206
\end{tabular}




\section{Fish Tag Recovery}

The discovery and recovery of fish tags began in autumn 2001 and extended to winter 2014; there were 1-3 annual visual searches totaling 24 search passes over a 14-year period. Searches took place when there were no pelicans on the island, which was from October through February, and consisted of teams of 3-14 people looking for fish tags for a 3-4 hour duration (typically between 1000 and 1400 hours). Searches took 5-6 days and 114-188 hours. Searches were considered equal effort, and time expended for each search influenced the number of tags encountered. When a fish tag was sighted, the searcher logged GPS location, tag type, color, and pertinent information on the tag (agency and identification number). Tag recovery densities were calculated using ArcGIS software (Environmental Systems Research Institute, 2010) to plot a percentage point density using the subcolony areas as a base layer. A variety of fish tags have been recovered over the course of this study (fig. A1). T-bar anchor tags deployed on cui-ui in the prespawning aggregation from 1989 through 1996 were of primary interest. This time period and location was particularly important because when tag collections from Anaho Island began in 2001, the tags deployed from this time period were virtually absent from adult fish in the prespawning aggregation, indicating few tags from this period were eliminated by birds in the colony after tag searches began (Scoppettone and others, 2014). This knowledge of presences at the time of our collection was critical in the estimation of the impact of pelicans on adult cui-ui survival. Tags deployed around the periphery of the lake in 1989-96 were not used because the large majority were juveniles (less than $300 \mathrm{~mm}$ fork length [FL]) and sufficiently small enough to have been consumed by double-crested cormorants, which have been observed foraging on fish up to about 295 mm FL (Hobson and others, 1989).

On survey passes 5 and 6, which occurred between 2003 and 2004, we used a Biomark ${ }^{\circledR}$ Scanner to detect PIT tags that we experimentally injected into 200 cui-ui that were fed to pelicans (not reported in table 1). The scanner also was used in an attempt to detect PIT tags from the 1,021 injected into cui-ui in 1988 and 1989. 


\section{Probability Experiment of Tag Recovery}

To estimate the number of cui-ui consumed by pelicans from tags recovered, tagged dead fish were fed to pelicans in the lower Truckee River to determine the chance of tag recovery in the pelican nesting colony. Feeding began in 2003 and extended to 2008 using only tagged dead cui-ui. There were 544 tagged dead adult cui-ui successfully fed to pelicans during this 6 years of feeding. The feeding of dead tagged fish greatly increased in 2011 and 2012 when Lahontan cutthroat trout (Onchorynchus clarkii henshawi) and common carp (Cyprinus carpio) were used as cui-ui surrogates. Methods of feeding and sizes of fish fed used in the experiment, as well as methods used for estimating probability of collecting these experimental tags within the Anaho Island nesting colony is described by Scoppettone and others (2014).

\section{Tag Dispersal and Recovery Experiment}

To determine the probability of detecting a cui-ui tag eliminated by a pelican on Anaho Island, 1,000 T-bar anchor tags (dispersal tags) were placed within the colony from February 10-16, 2012, before 2012 nesting began. Dispersal tags were a light blue color and similar to T-bar anchor tags deployed on cui-ui in the past and were identifiable by their label (the letters ANWR and a four-digit number). Each of the 1,000 tags was given a predetermined, randomized coordinate location using ArcGIS software (Environmental Systems Research Institute, 2010). The boundaries of the random coordinates were used from locations of tags that had been recovered from previous surveys within the sub-colonies. The overall percentage of tags recovered from each sub-colony was used to determine the number of coordinates to assign to each sub-colony. These random waypoints were loaded into GPS units and used for tag deployment (fig. 3).

Searches for dispersed ANWR tags were integrated into passes 21-24. Dispersed tags had been within the colony following one breeding season in searches 21-23 from October 20, 2012, to February 13, 2013. In search 24 from November 26, 2013, to February 21, 2014, dispersed tags had gone through two breeding seasons.

When a dispersed tag was located, the same information was collected as for the other tags except dispersed tags were returned to the exact spot they were recovered once all pertinent information was documented. 


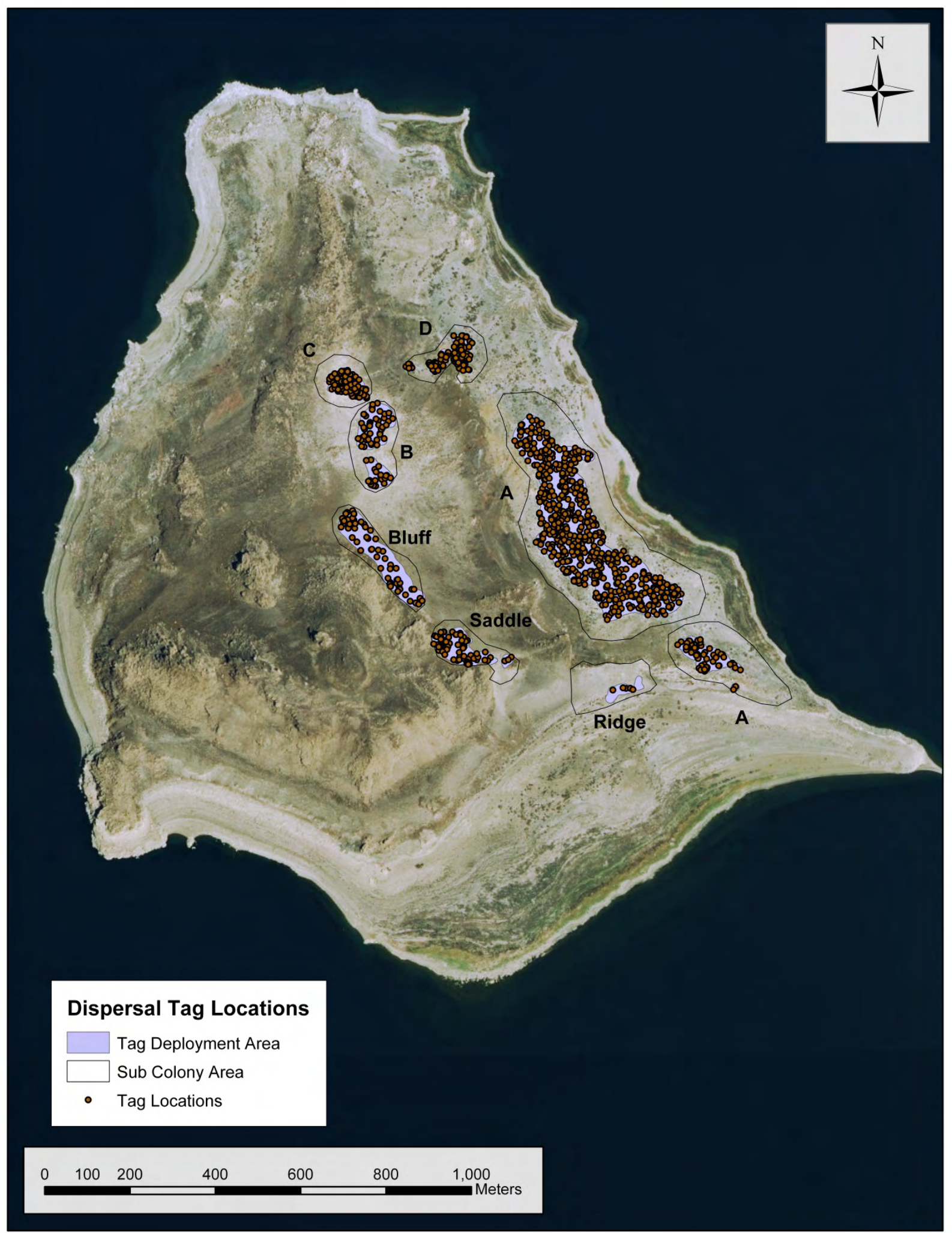

Figure 3. Locations of dispersal tags and tag deployment areas on Anaho Island nesting colony, Pyramid Lake, Nevada. 
We used a two sample Z-test to compare sample proportions (Stangroom, 2014) to determine if there was a significant difference in dispersal tag recoveries among passes of the same year (passes 2123) and over 2 years (passes 21-23 with 24):

$$
Z=\frac{\left(\bar{p}_{1}-\bar{p}_{2}\right)-0}{\sqrt{\bar{p}(1-\bar{p})\left(\frac{1}{n_{1}}+\frac{1}{n_{2}}\right)}}
$$

where

$p \quad$ is the proportion of dispersed tags recovered and $\mathrm{n}_{\mathrm{n}}$ is the total dispersed tags per search.

To account for differences in survey hours per pass, we adjusted the dispersal recovery percentage using the following formula:

$$
\mathrm{D} \text { tags }=\left[\mathrm{Tn}-\mathrm{T} \text { hour* }\left(\mathrm{Pn}-\mathrm{P}_{24}\right)\right] / 1,000
$$

where

$$
\begin{aligned}
\mathrm{T}_{n} & \text { is the number of tags recovered for each respective pass, } \\
\mathrm{T}_{\text {hour }} & \text { is the number of tags recovered per hour for each pass, } \\
\mathrm{P}_{n} & \text { are the hours for each pass, and } \\
\mathrm{P}_{24} & \text { is the total hours for pass } 24 \text {, which was used as the baseline. }
\end{aligned}
$$

We used a depletion estimator to calculate the total number of dispersal tags we would expect to find of the 1,000 tags had searches continued until all tags could be recovered. We used the jackknife regression heterogeneity model Mh (Polluck, 1990), as proposed by Chao (1987), in Program CAPTURE (Rexstad and Burnham, 1991) to calculate the depletion estimates.

\section{Tagged Fish Fed to Pelican and Tags Dispersed}

We used fish fed to pelicans and the tag dispersal study to calculate the relative percentage of cui-ui tags from the prespawning aggregation consumed and eliminated by birds outside of the pelican nesting colony. The estimated proportion of tags eliminated by birds outside of the colony was calculated using the following formula:

$$
\mathrm{E}=1.00-\mathrm{F} / \mathrm{D}
$$

where

$\mathrm{E} \quad$ is the number of cui-ui tags eliminated by birds outside the pelican nesting colony;

$\mathrm{F} \quad$ is the chance of finding a tag from a fed pelican in the nesting colony (for this study we used 5.3 percent the value generated by Scoppettone and others, 2014); and

$\mathrm{D}$ is the estimated percentage of dispersal tags in the nesting colony generated by the depletion calculation. 


\section{Results and Discussion}

\section{Cui-ui Tag Recovery}

Tags were recovered from almost all 36 years (1970-2006) of cui-ui tag deployment; recovered tags represented several tag types and deploying organizations (table 1). The tag with the longest history was a Carlin tag deployed on a fish by Dave Koch in spring 1972 (Koch, 1972) near the mouth of the Truckee River and recovered from the colony in 2004, 32 years following deployment. This Carlin tag was deployed on one of several of his tagged fish with no recorded data. The earliest T-bar anchor tag deployment was in 1982 from a cui-ui netted from the prespawning aggregation and recovered in the colony in winter 2002, 30 years following deployment. The presences of the dated Carlin and anchor tags is remarkable and may be due to them remaining on a live fish for many years before the fish was ingested by a pelican.

Another potential cause is that tags are continually buried and unearthed, which allows for their preservation, especially for the plastic T-bar anchor tag, which is especially subject to sun degradation. Although we scanned the entire colony twice (passes 5 and 6), we did not detect any of the 1,021 PIT tags injected into cui-ui from the prespawning aggregation or around the lake periphery in 1988 and 1989. This is understandable, because signals from these early developed PIT tags were relatively weak, and even slight burial within the colony rendered them undetectable. We did detect 6 of the 200 PIT tags injected into dead fed fish, probably because of their stronger signal. Fed fish injected with a PIT tag also harbored a T-bar anchor tag, which was used to determine probability of tag recovery; thus, the PIT tags are not reported in table 1 . The only sound or radio wave transmitting cui-ui tag we recovered from the colony was a 64-mm-long, 16-mm-wide sonic tag implanted in April 1982. The tag was from 1 of 11 sonic tags deployed in cui-ui captured and released in the prespawning aggregation and used to track lake movement (Scoppettone and others, 1986).

The large majority of tags deployed on cui-ui were from 1989 through 2006, with more than 251,000 tagged in the pre-spawning aggregation and an additional 84,500 around Pyramid Lake. From the 1989 to 2006 tag deployment, more than 10,000 were recovered from Anaho Island (table 1). The greatest return for prespawning aggregation fish came from those fish tagged from 1989 through 2000, with more than a 5.8 percent recovery rate. Recoveries from tags deployed from 2001 to 2006 were only 1.6 percent. We attribute these results partially to the use of almost 25,000 white-colored tags deployed from 2000 to 2003, which were extremely difficult to detect amongst white bones and shells resulting in only 0.003 percent recovery. Rate of recovery was higher for tags with dark colors (such as blue and green), probably due to the tags contrast with the light-colored substrate. Also, there is about a 4.0-5.0 percent annual shed rate of tags (Scoppettone and others, 2014), equating to a high number of tags shed before pelican predation in 2001-14 due to frequent years of drought and no cui-ui spawning migration. However, even in the wet year of 2006, when cui-ui were observed packed downstream of Marble Bluff Dam, few pelican focused on cui-ui predation, and apparently concentrated on a more reliable and continuous food source from another region of the Great Basin. Thus, cui-ui were less of a food source during the 2000s compared to the 1990s when there was a greater frequency of high water years. 
Cui-ui tags deployed from 1989 to 2006 were recovered throughout the Anaho Island nesting colony. However, there were areas with disproportionally high tag density such as seen in sub-colony A and in sub-colony D (fig. 4). With regard to sub-colony A, the first arrival of pelicans to the colony typically settles in sub-colony A, giving these birds a more protracted period to take cui-ui, contrasted to birds settled on sub-colonies Bluff, Saddle, and Ridge (fig. 4), which typically arrive later. Also, nesting occurred within sub-colony A on an annual basis, unlike sub-colony B and Bluff. High cui-ui tag density in sub-colony $\mathrm{D}$ also suggests heavy pelican use, but this sub-colony along with sub-colony $\mathrm{C}$ is localized and consequently receives inordinately high search attention and probably slightly skewed results. No nesting, or virtually no nesting, typically occurred in dry years when cui-ui where not readily available for predation, but even modest collections of tags over time contributes to sub-colony A's areas of high density. The cui-ui tag recovery history, as well as other species from Anaho Island between 2001 and 2014 is shown in appendix (table A1). Adult cui-ui consumed by pelicans ranged from 375 to $640 \mathrm{~mm}$ FL. The largest fish probably weighed about $3.5 \mathrm{~kg}$.

Searches were primarily within the pelican nesting colony, but we also recovered some tags outside sub-colony boundaries. Larger pre-fledging chicks have been observed moving to the shoreline, so perhaps birds fed there. Our subjective observation was that tags move in runoff events and in subcolonies with areas consisting of substantial sloping (Bluff, Ridge, B and C). Even at that, most tags appeared to remain within the confines of its respective sub-colony. 


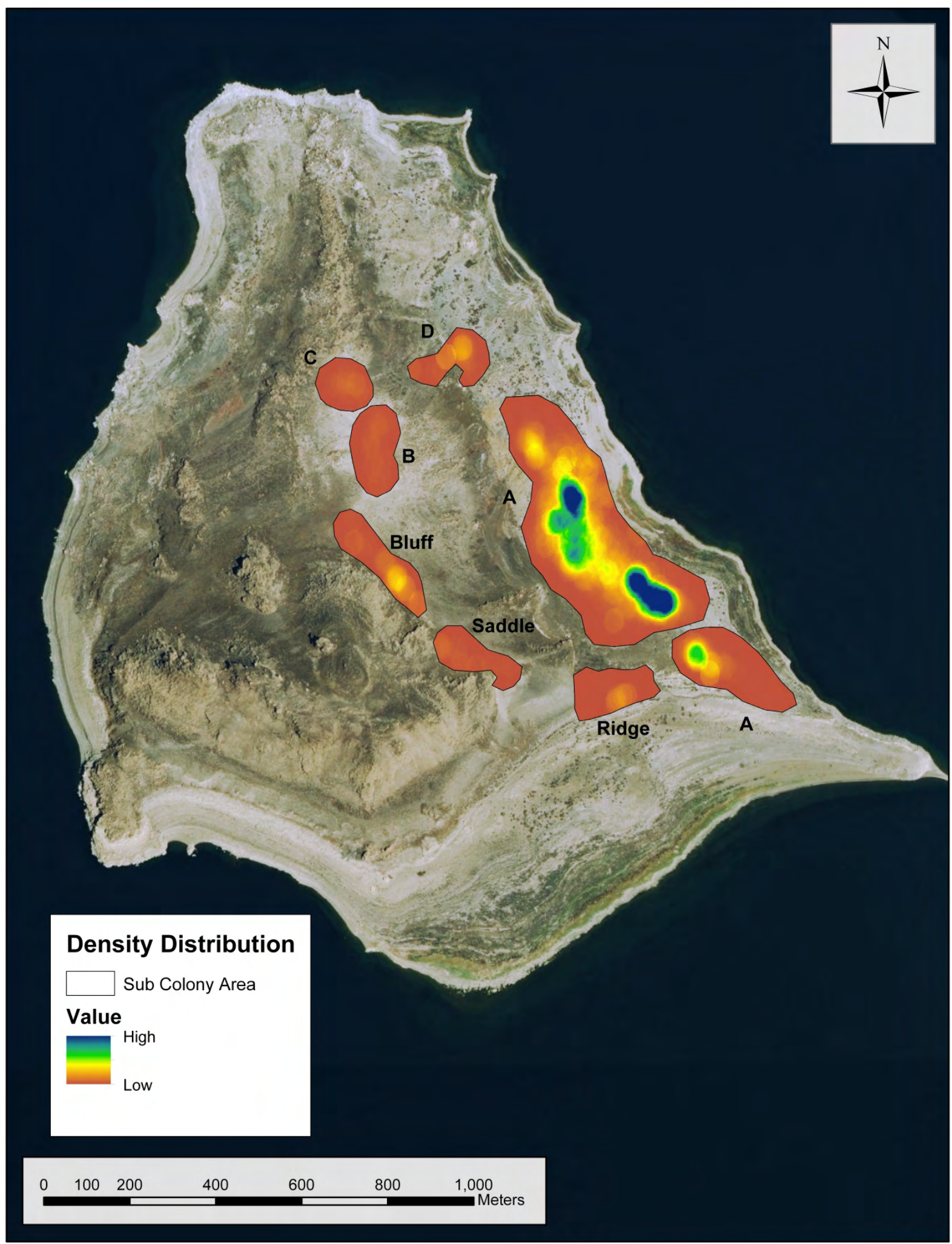

Figure 4. Density distribution of cui-ui (Chasmistes cujus) tags recovered from Anaho Island nesting sub-colonies, Pyramid Lake, Nevada, 2001-14. 


\section{Tagged Fish Fed to Pelicans}

In the springs of 2011 and 2012, we successfully fed 1,179 dead carp and trout as cui-ui surrogates to foraging pelican around the mouth of the Truckee River and at the mouth of the Marble Bluff Fishway. These fish ranged from 222 to $750 \mathrm{~mm}$ FL. Only 673 were adult cui-ui size (>375 mm FL) and used by Scoppettone and others (2014), because smaller fish had a significantly greater chance of being retrieved within the nesting colony (Scoppettone and others, 2014). We suspect the reason for this is that pelicans expel indigestible matter (bones, scales, tags) of larger fish before returning to the colony, improving flight take-off and energy efficiency. However, the addition of cui-ui-size carp and trout fed to pelicans brought the sample size of fish fed to pelicans to 1,219, more than double the previous sample size, where only adult cui-ui $(n=546)$ had been used. Of the 673 (>375 mm FL) carp and trout fed to pelicans, only 36 were recovered within the colony in the last seven passes (table 2). We estimated recoverable tags from adult cui-ui to be only 5.3 percent (95\% CI, 4.4-6.7\%) within the nesting colony (Scoppettone and others, 2014).

Table 2. Total number of tags recovered from 1,179 common carp (Cyprinus carpio) and Lahontan cutthroat trout (Oncorhynchus clarkii henshawi) fed to pelicans, Anaho Island nesting colony, Pyramid Lake, Nevada, springs of 2011 and 2012.

[Fish were released to foraging pelicans at the mouth of the Truckee River and Marble Bluff Fishway, Pyramid Lake, Nevada. Only 673 fish were greater than (>) 375 mm fork length (FL); mm, millimeter]

\begin{tabular}{|c|c|c|c|}
\hline \multirow[b]{2}{*}{ Pass } & \multicolumn{3}{|c|}{ Recovery occurrence } \\
\hline & $\begin{array}{c}\text { Common } \\
\text { carp }\end{array}$ & $\begin{array}{c}\text { Lahontan } \\
\text { cutthroat trout }\end{array}$ & $\begin{array}{c}\text { Fish } \\
>375 \mathrm{~mm} \mathrm{FL}^{*}\end{array}$ \\
\hline Pass 18 & 11 & 6 & 7 \\
\hline Pass 19 & 12 & 5 & 5 \\
\hline Pass 20 & 5 & 3 & 3 \\
\hline Pass 21 & 3 & 1 & 3 \\
\hline Pass 22 & 4 & 6 & 6 \\
\hline Pass 23 & 5 & 6 & 9 \\
\hline Pass 24 & 2 & 3 & 3 \\
\hline Total & 42 & 30 & 36 \\
\hline
\end{tabular}




\section{Tag Dispersal Study}

Of the 1,000 tags dispersed throughout the nesting colony, 45 percent $(n=446)$ were recovered in four passes (fig. 5). There were 123 different tags recovered in the first pass (pass 21 overall of the colony); 117 in the second pass (pass 22 overall); 119 in the third pass (pass 23 overall); and 87 in the fourth pass (pass 24 overall). Tags recovered in the first three passes occurred after one breeding season and in the fourth pass after two breeding seasons. Because the tags were returned to the exact location where they were recovered, some tags were encountered multiple times between passes; 339 tags were recovered once, 90 were recovered twice, 16 recovered three times, and only 1 was recovered in all four passes (table 3). Total number of individual tags recovered for each pass was used for the depletion estimator because tags were returned to their respective dispersal location.

Table 3. Total number of recovered tags dispersed throughout Anaho Island nesting colony, Pyramid Lake, Nevada.

[Passes 21-23 occurred from 2012 to 2013 after one pelican breeding season; pass 24 occurred from 2013 to 2014, following two breeding seasons]

\begin{tabular}{|c|c|c|c|c|c|}
\hline \multirow{2}{*}{ Survey } & \multicolumn{4}{|c|}{ Recovery occurrence } & \multirow{2}{*}{ Tota } \\
\hline & $1 s t$ & 2nd & 3rd & 4th & \\
\hline Pass 21 & 123 & & & & 123 \\
\hline Pass 22 & 85 & 32 & & & 117 \\
\hline Pass 23 & 72 & 39 & 8 & & 119 \\
\hline Pass 24 & 59 & 19 & 8 & 1 & 87 \\
\hline Total & 339 & 90 & 16 & 1 & 446 \\
\hline
\end{tabular}




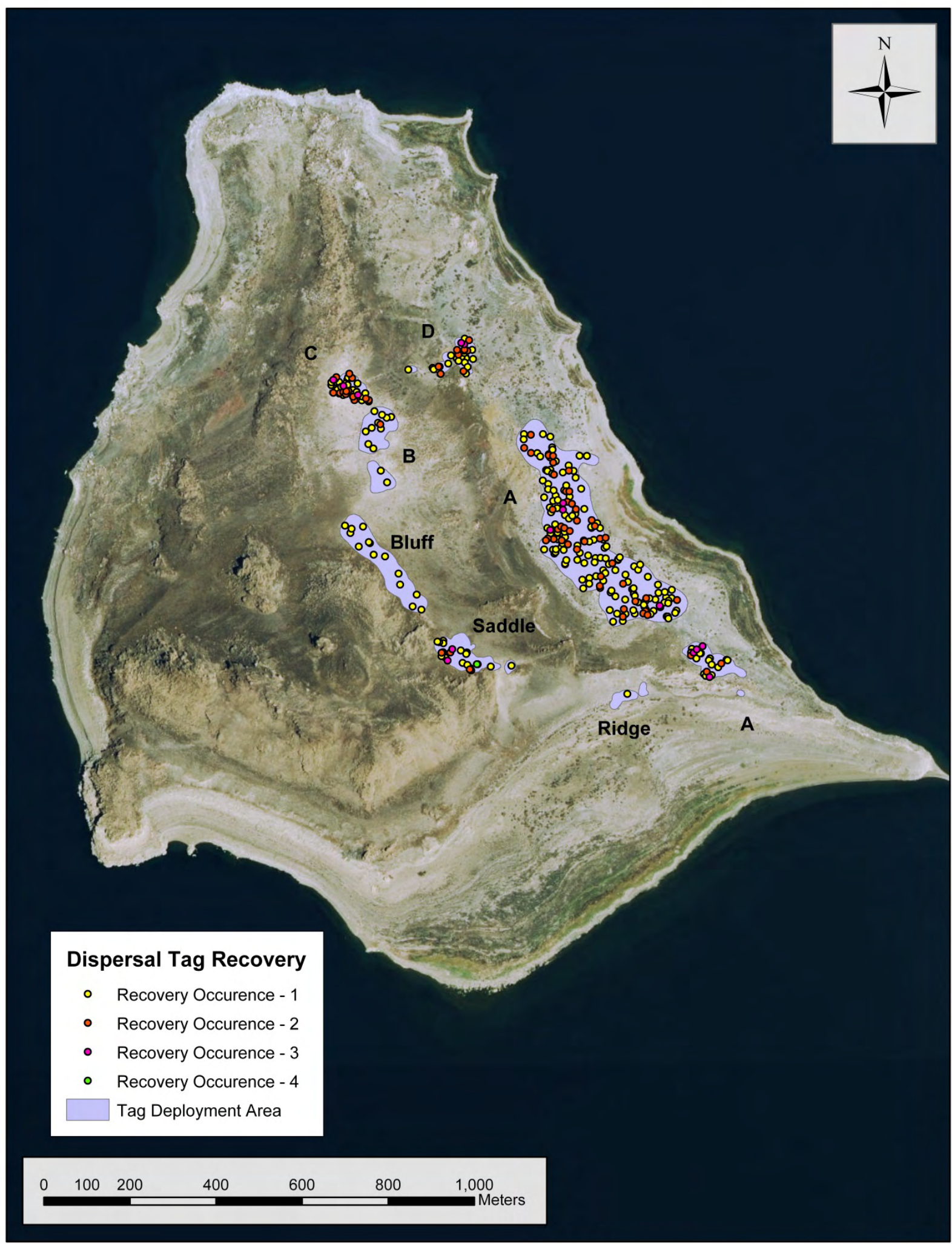

Figure 5. Areal distribution of recovered tags dispersed on the Anaho Island nesting colony, Pyramid Lake, Nevada. Passes 21-23 occurred from 2012 to 2013, after one pelican breeding season; pass 24 occurred from 2013 to 2014 , following two breeding seasons. 
The highest percentage of recovery was from sub-colony C (59.4 percent), and the lowest was from the Ridge (20.0 percent) (table 4). The Ridge had few experimental tags dispersed within its expansive area, so only one or two dispersed tag discoveries greatly influenced its results, while subcolony $\mathrm{C}$ is comparatively confined in area and has received little colony bird activity in the last several years prior to this study, enhancing the probability of tag recovery without bird disturbance (being buried by movement throughout the colony) before searches.

Table 4. Dispersal tags deployed by sub-colony, tags recovered, and frequency of tag recovery, Anaho Island nesting colony, Pyramid Lake, Nevada.

\begin{tabular}{lccc}
\hline Sub-colony & $\begin{array}{c}\text { Dispersal tags } \\
\text { deployed }\end{array}$ & $\begin{array}{c}\text { Dispersal tags } \\
\text { recovered }\end{array}$ & $\begin{array}{c}\text { Frequency } \\
\text { (percent) }\end{array}$ \\
\hline A & 621 & 277 & 44.6 \\
B & 63 & 16 & 25.4 \\
C & 101 & 60 & 59.4 \\
D & 88 & 45 & 51.1 \\
Bluff & 57 & 14 & 24.6 \\
Saddle & 65 & 33 & 50.8 \\
Ridge & 5 & 1 & 20.0 \\
\hline Total & 1,000 & 446 & \\
\hline
\end{tabular}

Tags recovered from passes 21-23 had been on Anaho Island after one breeding season, and tags recovered in pass 24 had been on the island following two breeding seasons. These two breeding seasons were in dry years with far less nesting activity on the island, equating to a few adults and their fledglings walking on and inadvertently burying tags in loose substrate.

The two sample $\mathrm{Z}$ tests suggest there is a significant reduction in the opportunity to recover dispersed tags after a breeding season, even following drought. There was no significant difference in recovery of dispersed tags between our first three passes in 2012-13 (table 5), but significantly less recovered in 2013-14. Future searches for these dispersed tags would slightly improve estimates of tags lost following a breeding season. If we had continued our passes to depletion, we calculated that there would be 515 (51.5 \%, 95\% CI 48.4-56.0 \%) initial encounters of the dispersed tags.

Table 5. Two sample Z-test to compare sample proportion for significance between tag recovery passes, Anaho Island nesting colony, Pyramid Lake, Nevada.

[Proportion is percentage of tags recovered per pass of the 1,000 tags dispersed. Two paired test where $\mathrm{p}$ is the number of identifiable tags recovered with significance at $\mathrm{p}<0.05]$

\begin{tabular}{lcrcccl}
\hline \multicolumn{1}{c}{ Pass } & Proportion & Pass & Proportion & $\mathbf{Z}$ & $\boldsymbol{p}$ & $\mathbf{p}<0.05$ \\
\hline 21 & 0.123 & 22 & 0.117 & 0.4129 & 0.68180 & no \\
21 & 0.123 & 23 & 0.119 & 0.2743 & 0.78716 & no \\
21 & 0.119 & 24 & 0.087 & 2.6259 & 0.00854 & yes \\
22 & 0.117 & 23 & 0.119 & -0.1386 & 0.88866 & no \\
22 & 0.117 & 24 & 0.087 & 2.2165 & 0.02642 & yes \\
23 & 0.119 & 24 & 0.087 & 2.3541 & 0.01878 & yes \\
Mean 21-23 & 0.120 & 24 & 0.087 & 2.4224 & 0.01552 & yes \\
\hline
\end{tabular}




\section{Tagged Fish Fed to Pelicans and Tag Dispersal}

Results of the tagged fish feeding and tag dispersal studies suggest most tags deployed on adult cui-ui in the prespawning aggregation are eliminated by birds outside of the nesting colony. From data generated from these studies and using the equation $\mathrm{E}=1.00-\mathrm{F} / \mathrm{D}$, we estimated that about 90 percent (95-\% CI 88.0-91.0\%) adult cui-ui tags are eliminated by birds outside of the nesting colony. This low percentage of cui-ui tags recovered on Anaho Island maybe due to the large size of cui-ui. After a pelican secures an adult cui-ui, it swims downstream into the lake rather than flying directly back to Anaho Island. We suspect that pelicans remain in the safety of aquatic habitat to digest their large catch and regurgitate indigestible matter (bones, scales, and foreign objects) into the lake. We found no sign of regurgitation of bones and other hard materials in loafing areas, which would serve as an attraction to coyotes and other potential predators.

Whole carcasses of adult cui-ui have been observed on Anaho Island, which may have been transported by the largest of birds. We also have witnessed pelicans swimming to Pyramid Lake from the Truckee River, presumably after ingesting a cui-ui, and then proceeding to swim toward Anaho Island until completely out of site. Thus, large carcasses may have been transported to Anaho Island by pelicans that swam the roughly $12 \mathrm{~km}$ reach. Although tags are probably regurgitated with hard matter off the island, Ferguson (2010) found that some fraction can remain in the bird's proventriculus for several days and then be eliminated by the bird in the colony, which may help to explain the numerous tags recovered in the nesting colony.

\section{Other Species}

\section{Salmonids}

There were more Lahontan cutthroat trout tags $(14,617)$ than cui-ui tags $(10,722)$ recovered from Anaho Island (table A1). The large majority of these were collected from 2006 to 2014 and associated with a juvenile Lahontan cutthroat trout tagging program initiated by the U.S. Fish and Wildlife Service (table 6). Most fish were stocked in spring-time in Pyramid Lake and the lower Truckee River (Nancy Vucinich, Pyramid Lake Fishery Biologist, oral commun., 2014), as well as in Walker Lake, by the Nevada Department of Wildlife and the U.S. Fish and Wildlife Service. Tags from juvenile Lahontan cutthroat trout stocked in the Truckee/Pyramid Lake system were in high density in and around cormorant nests indicating that these birds were their primary predator. There were relatively few tags from juvenile Lahontan cutthroat trout stocked in Walker Lake, and these generally were more closely associated with pelican nests. Approximately $160 \mathrm{~km}$ from Anaho Island, Walker Lake is well outside the $30 \mathrm{~km}$ foraging range of double-crested cormorant (Hatch and Weseloh, 1999), but within the foraging range of the more efficiently flying American White Pelican (Evans and Knopf, 1993). 
Table 6. History of salmonid tags recovered from Anaho Island nesting colony, Pyramid Lake, Nevada.

[CDFW, California Department of Wildlife; CDWR; California Department of Water Resources; NDOW, Nevada Department of Wildlife; PLPT, Pyramid Lake Paiute Tribe; Private, Private Fish Derby; Sigler, Sigler and Associates; USFS, U.S. Forest Service; USFWS, U.S. Fish and Wildlife Service. km, kilometer]

\begin{tabular}{|c|c|c|c|c|c|}
\hline $\begin{array}{c}\text { Release } \\
\text { organization }\end{array}$ & Tag type & $\begin{array}{l}\text { Deployment } \\
\text { date }\end{array}$ & Location & $\begin{array}{l}\text { Number of tags } \\
\text { recovered }\end{array}$ & $\begin{array}{l}\text { Distance } \\
(\mathrm{km})\end{array}$ \\
\hline \multicolumn{6}{|c|}{ Lahontan cutthroat trout } \\
\hline Sigler & T-bar anchor & 1975-1976 & Pyramid Lake & 4 & $0-5$ \\
\hline PLPT & T-bar anchor & $\begin{array}{l}\text { 1993, 2000-04, } \\
2011-13\end{array}$ & Pyramid Lake & 825 & $0-5$ \\
\hline USFWS & T-bar anchor & $2000 s$ & Pyramid Lake & 13,561 & NA \\
\hline USFWS & T-bar anchor & 2000s & Walker Lake & 194 & 155 \\
\hline NDOW & T-bar anchor & 2006 & Walker Lake & 31 & 155 \\
\hline NDOW & T-bar anchor & 2005 & Truckee River & 2 & 55 \\
\hline \multicolumn{6}{|l|}{ Rainbow trout } \\
\hline CDFW & Carlin & 1985 & Lake Isabella & 1 & 510 \\
\hline CDFW & Carlin & $1982-2000$ & Eagle Lake & 49 & 130 \\
\hline CDFW & Carlin & 1995 & Baum Lake & 1 & 205 \\
\hline CDFW & Carlin & 1998 & Lake Davis & 1 & 90 \\
\hline Private & T-bar anchor & 2000 & Weber Lake & 8 & 110 \\
\hline CDFW & T-bar anchor & 2001-2003 & Boca Reservoir & 2 & 80 \\
\hline Private & T-bar anchor & 2005 & Crowely Lake & 1 & 270 \\
\hline CDFW & T-bar anchor & 2008 & Lake Davis & 10 & 90 \\
\hline Private & T-bar anchor & 2012 & Lake Isabella & 3 & 510 \\
\hline NDOW & T-bar anchor & 2010-11 & $\begin{array}{l}\text { Topaz Lake or } \\
\text { Hinkson Slough }\end{array}$ & 46 & $125-140$ \\
\hline USFS & Radio & 2004 & Eagle Lake & & 130 \\
\hline \multicolumn{6}{|l|}{ Chinook salmon } \\
\hline CDWR & T-bar anchor & 2006 & Feather River & & 175 \\
\hline
\end{tabular}


Large Lahontan cutthroat trout (>400 mm total length - TL) are consumed exclusively by American White Pelican, the only bird within the nesting colony capable of consuming such large fish (Evans and Knopf, 1993). Pelicans secure large Lahontan cutthroat trout on their spawning migration up the Truckee River, Marble Bluff Fishway, and the spawner channel at Sutcliffe. However, tags deployed are on trout after they were spawned at the Sutcliffe channel, suggesting that some may be in a more weakened condition. Numerous hooked lures and stringer ropes recovered from the nesting colony (fig. 6) suggest that pelicans benefit from hooked fish escapes of fisherman that are taken dead or flailing at the surface.

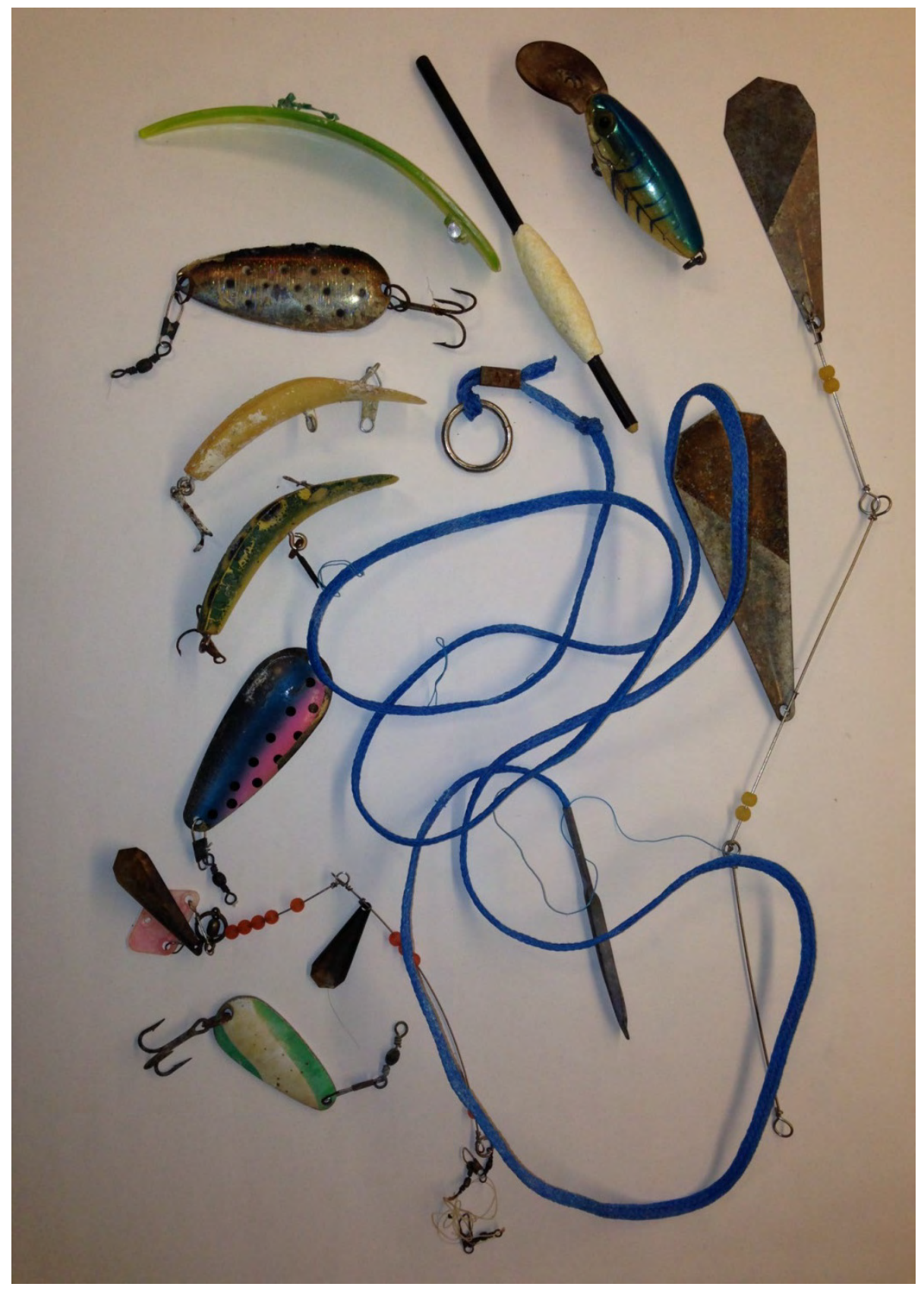

Figure 6. Assortment of hooked lures and stringers gathered from the Anaho Island nesting colony, Pyramid Lake, Nevada, 2001-2014. 
The oldest probable Lahontan cutthroat trout tags recovered from the Anaho Island nesting colony were deployed between 1975 and 1977 by W.F. Sigler and Associates, Inc., who conducted an ecological study of Pyramid Lake (Sigler and others, 1978). Their report indicated that they captured and tagged trout from around Pyramid Lake. These tags remained within the nesting colony for probably more than 20 years before their recovery. Finding these tags, as well as those deployed by Koch (1972) and the U.S. Fish and Wildlife Service (written commun., 2014), deposited within the existing nesting colony is remarkable, not only from the standpoint of duration; we observed from old abandoned nest sites that nesting area has shifted over time. Our tag recoveries suggest that some nesting areas of the colony have been used for decades.

Rainbow trout (Oncorhynchus mykiss) tags collected from the colony came from the greatest number of deployment areas. Judging from the distances that tagged fish were taken, most were probably taken by pelicans. The greatest distance was from Lake Isabella in southern California, approximately $510 \mathrm{~km}$ from Anaho Island (fig. 7). Fish captured there were from a fishing derby, and we suspect captured by pelicans on their late winter/early spring migration from southern California and Mexico to the nesting colony at Anaho Island. Rainbow trout from Lake Davis were probably the largest brought to the colony (>500 mm TL) and were stocked by California Department of Fish and Wildlife to provide an immediate fishery following a chemical treatment of the lake to extirpate northern pike (Esox Lucius) (California Department of Fish and Wildlife, written commun., 2009). Eagle Lake contributed the greatest number of tags from rainbow trout, 49 Carlin tags deployed by the California Department of Fish and Wildlife, and a single radio tag deployed by the U.S. Forest Service (table 5). The location contributing the second greatest number of rainbow trout tags to the nesting colony is unclear because rainbow trout tagged at Mason Fish Hatchery, Lyon County in 2010 and 2011 by Nevada Department of Wildlife were split between Topaz Lake, Douglas County, Nevada, and Hinkson Slough, Lyon County, Nevada.

The only other salmonid species represented by tag collections from the Anaho Island nesting colony was from a Chinook salmon (Oncorhynchus tshawytscha) tagged in 2006 and taken on the Feather River downstream of Lake Oroville, California. 


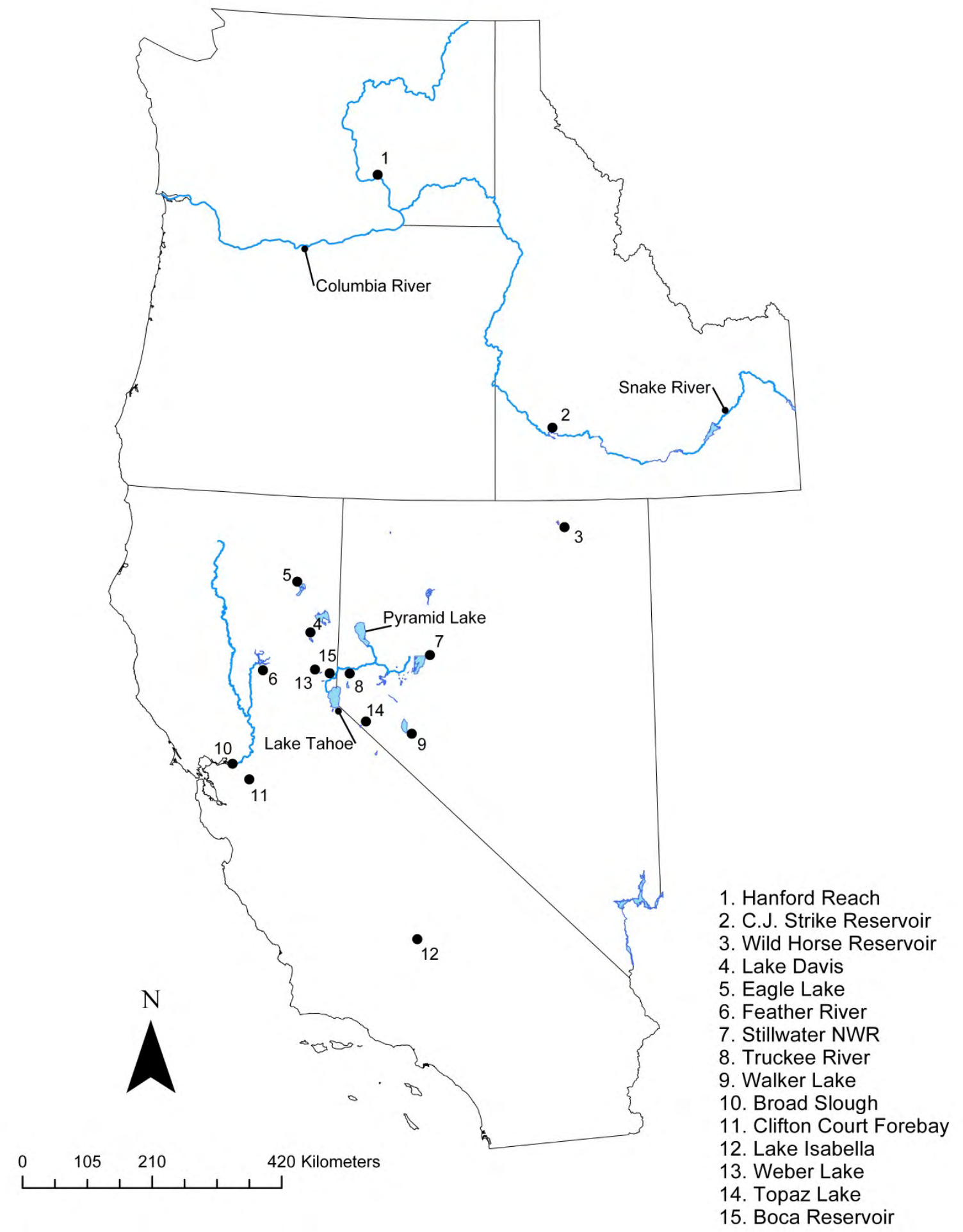

Figure 7. Locations of tagged fish deployment taken by American White Pelican (Pelecanus erythrorhynchos) back to Anaho Island nesting colony, Pyramid Lake, Nevada. 


\section{Spiny Ray Fishes}

Other fishes represented by recovery of tags from the Anaho Island occur in table 7. Among these were five striped bass (Morone saxatilis) from the San Francisco Bay Delta. Finding these tags fit with the movement behavior observed by Seegar and Fuller (1997), who satellite-tracked pelicans flying from Anaho Island over the Sierra Nevada mountain range to the San Francisco Bay Delta and returning to the island after 2-3 days. This pattern gave these birds sufficient time to secure prey and partially digest their take while purging indigestible components (scales, bones), facilitating flight back to Anaho Island. We suspect these forays over the Sierra Nevada to secure food occur primarily in dry years when there is reduced forage within $50 \mathrm{~km}$ of Anaho Island. Movement patterns of American White Pelican from their nesting site at Anaho Island in wet years compared to drought years certainly is an area where further research is needed. How and why tags from some other locations arrived on the Anaho Island colonial bird nesting colony are, at this point inexplicable. For example, the flight to the Columbia River was well over twice the distance of birds foraging and returning from the San Francisco Bay Delta (fig. 7). Trips to the Snake River were also substantially farther than to the San Francisco Bay Delta. Again, further study is needed to better interpret the significance of this substantial movement. For example, are birds moving these distances to secure forage to continue nesting when foraging opportunities are poor within the immediate nesting area, or are these birds abandoning nesting efforts and only inadvertently returning to the nesting colony, or are they young non-nesting birds that do not return to the nesting colony on a regular annual basis. This information can be obtained by tracking pelicans associated with demographic, behavior, and movement of Anaho Island colonial bird nesting habitat.

Table 7. History of spiny ray fish tags recovered from Anaho Island nesting colony, Pyramid Lake, Nevada.

[CDFW, California Department of Fish and Wildlife; IDFG, Idaho Department of Fish and Game; NDOW, Nevada Department of Wildlife; ODFW, Oregon Department of Fish and Wildlife. km, kilometer]

\begin{tabular}{|c|c|c|c|c|c|}
\hline $\begin{array}{c}\text { Release } \\
\text { organization }\end{array}$ & Tag type & $\begin{array}{l}\text { Deployment } \\
\text { date }\end{array}$ & Location & $\begin{array}{l}\text { Number of } \\
\text { tags } \\
\text { recovered }\end{array}$ & $\begin{array}{c}\text { Distance } \\
(\mathrm{km})\end{array}$ \\
\hline \multicolumn{6}{|l|}{ White crappie } \\
\hline IDFG & T-bar anchor & 2007 & Snake River & 1 & 440 \\
\hline \multicolumn{6}{|c|}{ Northern pikeminnow } \\
\hline ODFW & T-bar anchor & 1998 & Columbia River & 1 & 735 \\
\hline \multicolumn{6}{|l|}{ Striped bass } \\
\hline CDFW & Disc & 1993-2009 & San Francisco Bay Delta & 7 & 310 \\
\hline \multicolumn{6}{|l|}{ Smallmouth bass } \\
\hline IDFG & Jaw & 2009 & Snake River & 1 & 440 \\
\hline \multicolumn{6}{|l|}{ Wiper } \\
\hline NDOW & T-bar anchor & 2008 & Wild Horse Reservoir & 1 & 355 \\
\hline
\end{tabular}




\section{Conclusions}

1. The primary tag recovery focus was for the federally listed endangered cui-ui.

2. Cui-ui tags were recovered that had been deployed more than 30 years before their recovery from the Anaho Island nesting colony.

3. The chance of finding a tag from an adult cui-ui taken by a pelican is only 5.3 percent within the Anaho Island nesting colony.

4. Once a tag arrives within the nesting colony, there is about a 51.5 percent chance of finding it when searching to depletion.

5. More than 90 percent of tags from adult cui-ui are eliminated by birds outside of the nesting colony.

6. Tags from adult cui-ui are suspected to be eliminated by birds in Pyramid Lake.

7. Most numerous tags were from Lahontan cutthroat trout, and tag distribution within the nesting colony suggested double-crested cormorants as the primary predator.

8. The fish species brought in from the greatest number of waters (10) was the rainbow trout.

9. Fish from Eagle Lake, California, was the greatest contributor of rainbow trout tags.

10. Tag recoveries indicate that fish were brought to Anaho Island as far away as San Francisco Bay, California, Columbia River, Washington, and Snake River, Idaho, and other areas with distances more than $150 \mathrm{~km}$.

11. Studies that focus on the Anaho Island population of American White Pelican movement patterns in relation to wet and dry years may be useful and informative.

\section{Acknowledgments}

We would like to thank the U.S. Fish and Wildlife Service Stillwater National Wildlife Complex for allowing us access onto this unique refuge and for funding this project through Intra-Governmental Agreements 84320-9-H430 (06/16/2011) and 4500038818 (08/13/2012). We would also like to thank all those who assisted over the years in tag searches on Anaho Island, too numerous to list here. 


\section{References Cited}

Chao, A., 1987, Estimating the population size for capture-recapture data with unequal catchability: Biometrics, v. 43, p. 783-791.

Collis, K.S., Roby, D.D., Craig, D.P., Adamany, S., Adkins, J.Y., and Lyons, D.E., 2002, Colony size and diet composition of piscivorous water birds on the lower Columbia River-Implications for losses of juvenile salmonids to avian predation: Transactions of the American Fisheries Society, v. 131, p. 537-550.

Collis, K.S., Roby, D.D., Craig, D.P., Ryan, B.A., and Ledgerwood, R.D., 2001, Colonial water bird predation on juvenile salmonids tagged with passive integrated transponders in the Columbia River estuary - Vulnerability of different salmonid species, stocks and rearing types: Transactions of the American Fisheries Society, v. 130, p. 385-396.

Dalton, C.M., Ellis, D., and Post, D.M., 2009, The impact of double-crested cormorants (Phalacrocorax auritus) predation on anadromous Alewife (Alosa pseudoharengus) in south-central Connecticut, USA: Canadian Journal of Fisheries and Aquatic Sciences, v. 66, p. 177-186.

Derby, C.E., and Lovvorn, J.R., 1997, Predation on fish by cormorants and pelicans in a cold-water river-A field and modeling study: Canadian Journal of Fisheries and Aquatic Sciences, v. 54, p. 1,480-1,493.

Environmental Systems Research Institute, 2010, ArcGIS Desktop: Release 10. Redlands, CA: Environmental Systems Research Institute.

Evans, R.M., and Knopf, F.L., 1993, American white pelican: The Birds of North America, v. 57, no. 1-20.

Ferguson, T.L., 2010, Nutrient utilization by diet preference of American white pelican when offered diets of Channel Catfish and (or) Grass Carp: Starkville, Mississippi State University, Master's thesis.

Glancy, P.A., Van Denburgh, A.S., and Born, S.M., 1972, Runoff, erosion, and solutes in the lower Truckee River, Nevada, during 1969: Water Resources Bulletin, v. 8, p. 1,157-1,172.

Hatch, J.J., and Weseloh, D.V., 1999, Double-crested Cormorant (Phalacrocorax auritus), in Poole, A., and Gill, F., eds., The Birds of North America: The Academy of Natural Sciences, Philadelphia, Pennsylvania, and the American Ornithologists Union, Washington, D.C.

Hobson, K.A., Knapton, R.W., and Lysack, W., 1989, Population, diet and reproductive success of double-crested cormorants breeding on Lake Winnipegosis, Manitoba, in 1987: Colonial Waterbirds, v. 12, p. 191-197.

Koch, D.L., 1972, Life history information on the Cui-ui lake sucker (Chasmistes cujus Cope, 1883) endemic to Pyramid Lake, Washoe County, Nevada: Reno, University of Nevada, Doctoral dissertation.

La Rivers, I., 1962, Fishes and fisheries of Nevada: Reno, Nevada Fish and Game Commission, 782 p.

Madenijan, C.P., and Gabrey, S.W., 1995, Waterbirds predation on fish in western Lake Erie-A bioenergetics model application: The Condor, v. 97, p. 141-153. 
Pollock, K.H., Nichols, J.D., Brownie, C., and Hines, J.E., 1990, Statistical inference for capturerecapture experiment: Wildlife Monographs, v. 107, p. 1-97.

Rexstad, E., and Burnham, K.P., 1991, User's guide for interactive program CAPTURE: Fort Collins, Colorado State University, Colorado Cooperative Fish and Wildlife Research Unit.

Scoppettone, G.G., Coleman, M., and Wedemeyer, G.A., 1986, Life history and status of the endangered Cui-ui: U.S. Fish and Wildlife Service, Fish and Wildlife Research 1.

Scoppettone, G.G., Rissler, P.H., Fabes, M.C., and Shea, S.P., 2015, Population Dynamics of the Cui-ui of Pyramid Lake, Nevada: a potamodromous Catostomid Subject to Failed Reproduction: North American Journal of Fisheries Management, v. 35, no. 5, p. 853-864.

Scoppettone, G.G., Rissler, P.H., Fabes, M.C., and Withers, D., 2014, American White Pelican predation on Cui-ui in Pyramid Lake, Nevada: North American Journal of Fisheries Management, v. 34, no. 1, p. 57-67.

Scoppettone, G.G., Rissler, P.H., Buettner, M.E., 2000, Reproductive longevity and fecundity associated with non-annual spawning in Cui-ui: Transactions of the American Fisheries Society, v. 129, p. 658-669.

Scoppettone, G.G., Rissler, P.H., Withers, D., and Fabes, M.C., 2006, Fish tag recovery from the American white pelican nesting colony on Anaho Island, Pyramid Lake Nevada: Great Basin Birds, v. 8, p. 6-10.

Seegar, W.S., and Fuller, M.R., 1997, Legacy demonstration of technologies and methodologies relevant to military natural resources conservation: Aberdeen Proving Ground, Maryland, Edgewood Research, Development and Engineering Center.

Sigler, W.F., Helm, W.T., Ducera, P., Robertson, D., and Vigg, S., 1978, Life history of Lahontan cutthroat trout Salmo clarki henshawi, in Sigler W.F., and Kennedy, J.L., eds., Pyramid Lake ecological study: Logan, Utah, W.F. Sigler \& Associates, Inc.

Sonnevil, G.M., 1981, Evaluation of the cui-ui restoration program-1977-1980: Special Report Endangered Species Program, U.S. Fish and Wildlife Service, 34 p.

Stangroom, J., 2014, Z test calculator for 2 population proportions: Social Science Statistics, http://www.socscistatistics.com/tests/ztest/.

Wiese, F.K., Parrish, J.K., Thompson, C.W., and Maranto, C., 2008, Ecosystem-based management of predator-prey relationships-Piscivorous birds and salmonids: Ecological Applications, v. 18, p. 681-700. 


\section{Appendix A}

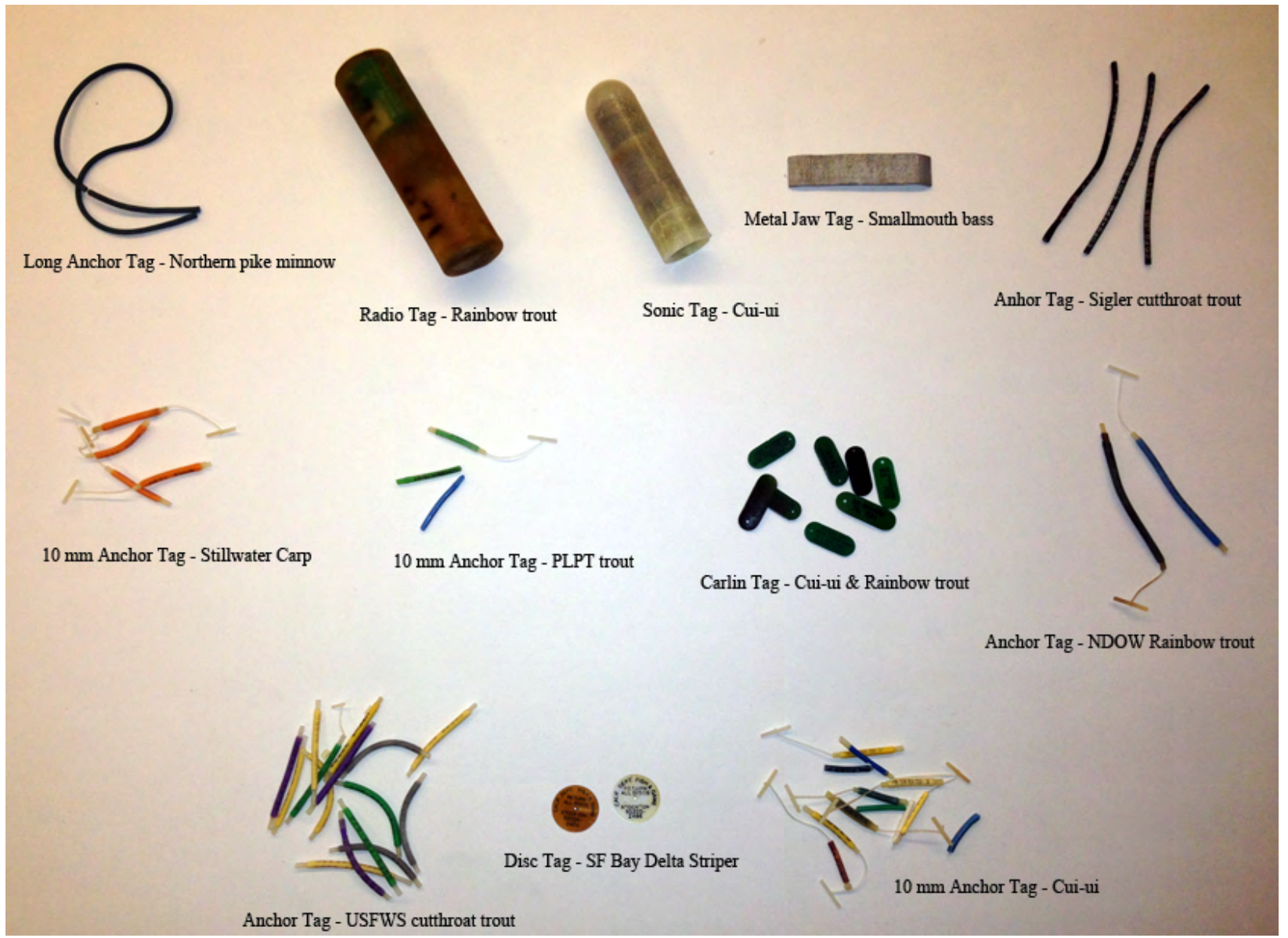

Figure A1. Types of fish tags recovered from the Anaho Island nesting colony, Pyramid Lake, Nevada, 2001-2014. 
Table A1. Number of identifiable tags recovered from the Anaho Island nesting colony, Pyramid Lake, Nevada, 2001-14.

[Table A1 is a Microsoft ${ }^{\circledR}$ Excel file and can be downloaded at http://dx.doi.org/10.3133/ofr20151242] 
Publishing support provided by the U.S. Geological Survey

Science Publishing Network, Tacoma Publishing Service Center

For more information concerning the research in this report, contact the Director, Western Fisheries Research Center U.S. Geological Survey

6505 NE 65th Street

Seattle, Washington 98115

http://wfrc.usgs.gov/ 
